\title{
Parvovirus B19-induced constellation of acute renal failure, elevated aminotransferases and congestive heart failure
}

\author{
IAIN W MCAULEY MD, FARSHAD SEPANDJ MD FRCPC, WALTER SCHLECH MD FRCPC
}

\begin{abstract}
IW MCAULEY, F SEPANDJ, W SCHLECH. Parvovirus B19-induced constellation of acute renal failure, elevated aminotransferases and congestive heart failure. Can J Infect Dis 1997;8(1):53-55. This report details a case of acute renal failure and elevated aminotransferases with subsequent development of congestive heart failure in a patient with history of exposure to parvovirus B19 and serological evidence of acute infection with this agent. This constellation of organ involvement has not been previously reported in the literature.
\end{abstract}

Key Words: Acute renal failure, Aminotransferases, Congestive heart failure, Parvovirus B19

\section{Insuffisance rénale aiguë, élévation des aminotransférases et insuffisance cardiaque induites par le parvovirus B19}

RÉSUMÉ : Ce rapport décrit en détails un cas d'insuffisance rénale aiguë, d'élévation des aminotransférases avec insuffisance cardiaque subséquente chez un patient ayant été infecté au parvovirus B19, épreuves sérologiques de l'infection aiguë à l'appui. Cette constellation d'atteintes organiques n'avait encore jamais été signalée dans la littérature.

$\mathrm{P}^{\mathrm{a}}$ arvovirus B19 was discovered in 1975 during serum screening of normal blood bank donors for hepatitis B antigen in lot B, sample 19, hence the name (1). In 1981 it was shown to have a causative role in transient aplastic crises of patients with chronic hemolytic anemia $(2,3)$, and in 1985 was identified as the agent causing the childhood illness erythema infectiosum, so-called 'fifth disease' or 'slapped cheek syndrome' (4). Outbreaks of fifth disease primarily affect children in schools or day care centres. In reported outbreaks, $10 \%$ of the cases are in those under age five years, $70 \%$ in those from ages five to 15 years and $20 \%$ of cases are in those older than 15 years (5). Infections tend to be seasonal and are more common in late winter and spring (6). Approximately half of the adult population has been exposed to this agent and acquired immunity between the ages of five and 19 years, with seroprevalence increasing with age $(7,8)$. Adult infections may vary considerably in severity, and the spectrum of illness can include 'flu-like symptoms, generalized pruritus, arthropathy, joint effusions, anemia, myositis, encephalitis and idiopathic thrombocytopenic purpura (6).

Divisions of Nephrology and Infectious Diseases, Dalhousie University, Halifax, Nova Scotia

Correspondence: Dr F Sepandj, Division of Nephrology, Foothills Hospital, 1403, 29th Street Northwest, Calgary, Alberta T2N 2T9. Telephone 403-670-2804, fax 403-670-4988

Received for publication March 11, 1996. Accepted June 6, 1996 


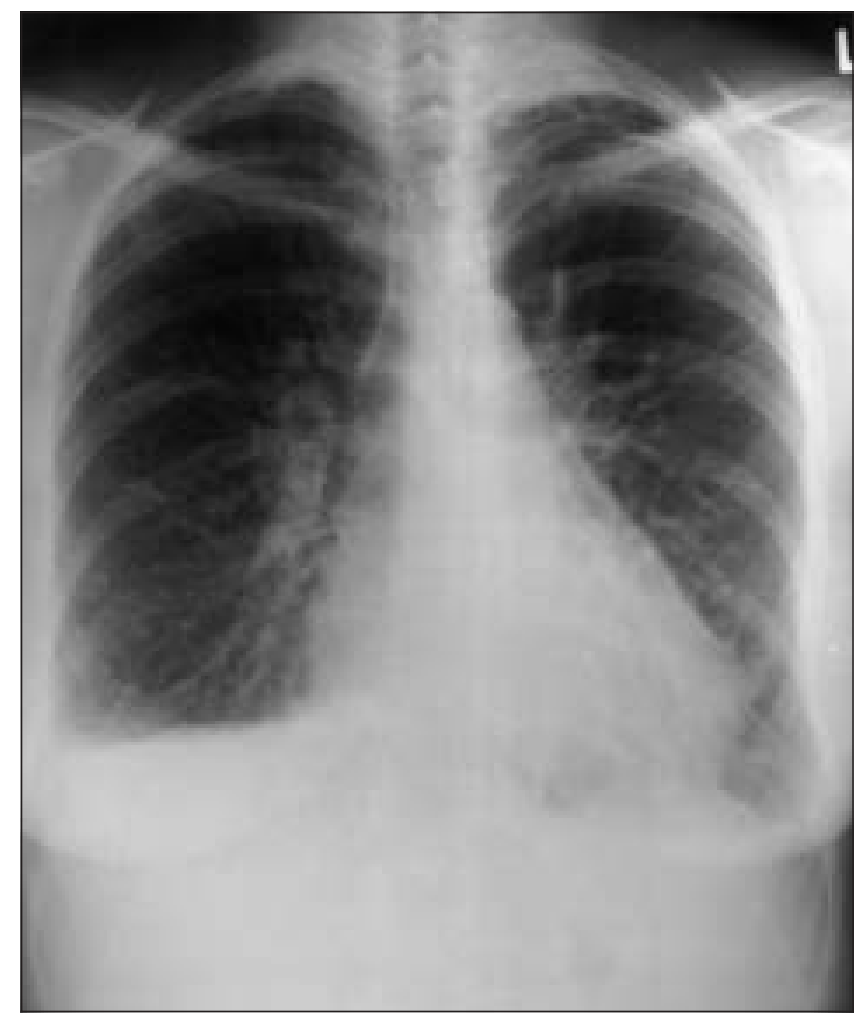

Figure 1) Chest $x$-ray demonstrating cardiomegaly, pulmonary vascular redistribution, hilar and pulmonary edema and blunting of costophrenic angles, suggestive of congestive heart failure

A case of parvovirus B19 infection in an adult is presented. The patient had recent exposure to parvovirus B19 which resulted in acute renal failure, transient elevation of liver enzymes and congestive heart failure.

\section{CASE PRESENTATION}

A previously healthy 39-year-old female nurse developed a 'flu-like illness with fatigue, malaise, headache, arthralgias and a low grade fever. Her son had developed a similar illness along with a cutaneous rash approximately two weeks earlier and was diagnosed with erythema infectiosum ('fifth disease') by his pediatrician, based on clinical presentation and positive serology. With the exception of persistent fatigue, all other symptoms subsided within 10 days; however, over the next three days she developed generalized edema with $7 \mathrm{~kg}$ weight gain. She was evaluated by her family doctor, and laboratory studies revealed acute renal failure (serum creatinine of $251 \mu \mathrm{mol} / \mathrm{L}$ [normal range 60 to $110 \mu \mathrm{mol} / \mathrm{L}$ ]), normocytic, normochromic anemia (hemoglobin $93 \mathrm{~g} / \mathrm{L}$ [115 to $155 \mathrm{~g} / \mathrm{L}]$ ) with reticulocyte count $2.0 \%$ (0.9\% to $2.6 \%$ ) and elevated liver enzymes (aspartate aminotransferase $58 \mathrm{U} / \mathrm{L}$ [8 to $29 \mathrm{U} / \mathrm{L}$ ], alanine aminotransferase $80 \mathrm{U} / \mathrm{L}$ [1 to $20 \mathrm{U} / \mathrm{L}$ ], lactate dehydrogenase $311 \mathrm{U} / \mathrm{L}$ [108 to $211 \mathrm{U} / \mathrm{L}])$, but normal direct ( $2 \mu \mathrm{mol} / \mathrm{L}$ [0 to $4 \mu \mathrm{mol} / \mathrm{L}$ ]) and total $(14 \mu \mathrm{mol} / \mathrm{L}$ [0 to 16 $\mu \mathrm{mol} / \mathrm{L}])$ bilirubin. Urinalysis showed no hematuria and trace proteinuria on dipstick, and the urine sediment was inactive with no red or white blood cells, crystals or casts on microscopy. Renal function had improved two days later when the

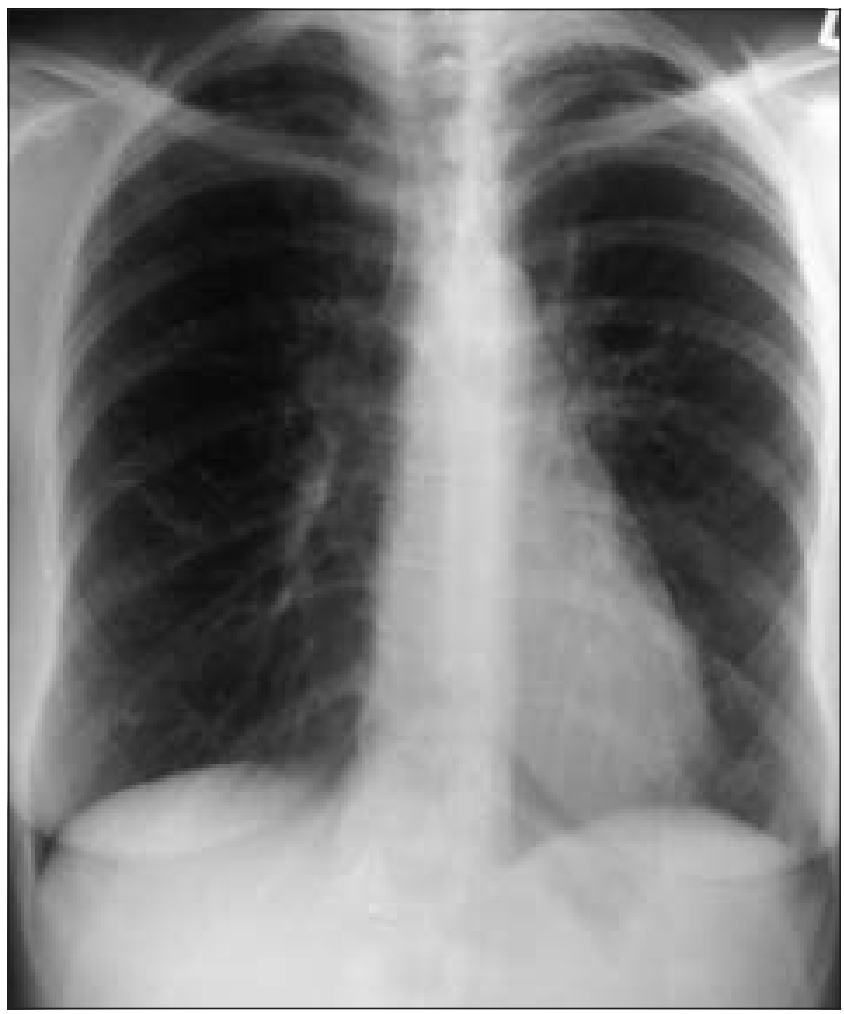

Figure 2) Follow-up study nine months later with resolution of patient's symptoms

patient was seen in the nephrologist's office (serum creatinine down to $191 \mu \mathrm{mol} / \mathrm{L}$ ); however, by follow-up five days later she had developed exertional dyspnea, orthopnea and paroxysmal nocturnal dyspnea. Examination (20 days after the onset of symptoms) revealed that jugular venous pressure was elevated at $5 \mathrm{~cm}$ above the sternal angle, and she had a prominent apical impulse, a third heart sound and bibasilar crepitations findings suggestive of congestive heart failure. Chest x-ray demonstrated an enlarged heart, bilateral blunting at the costophrenic angles, increased interstitial markings, Kerley B lines and perihilar edema, confirming the clinical diagnosis of congestive heart failure (Figure 1). Electrocardiogram demonstrated sinus tachycardia at 110 beats/min with no ST-T changes. Creatine kinase (CK) was slightly elevated at $157 \mathrm{U} / \mathrm{L}$ ( 15 to $20 \mathrm{U} / \mathrm{L}$ ) with a CK-MB fraction of $1 \mathrm{U} / \mathrm{L}$ (relative index of less than 1\%). Antinuclear antibody, antiDNA, extractable nuclear antigen and anticardiolipin antibody were all negative. Complement studies showed a normal C4 and marginally reduced C3 at $844 \mathrm{mg} / \mathrm{L}$ ( 870 to $1720 \mathrm{mg} / \mathrm{L}$ ). Serological studies for syphilis, hepatitis B and C, human immunodeficiency virus, Epstein-Barr virus and Borrelia burgdorferi were all negative. An echocardiogram revealed a mild decrease in left ventricular fractional shortening (33\%), and wall motion study confirmed a similar abnormality with slight global reduction of her ejection fraction (54\%). Ventilation-perfusion scan and Doppler ultrasound examination of her leg veins were negative. Parvovirus B19 serology at this time (day 22) in hospital showed positive titres for both immunoglobulin $\mathrm{M}$ 
and G. A diagnosis of parvovirus B19-induced acute renal failure, elevated liver enzymes and congestive heart failure was made.

The patient was treated symptomatically with oxygen and intravenous furosemide. Over the following week her hemoglobin level gradually rose, and her creatinine and liver enzymes level fell towards the normal liver function range. A repeat echocardiogram demonstrated an increase in the left ventricular fractional shortening to $40 \%$. She was discharged home on short term oral furosemide therapy, and her recovery was followed as an out-patient. Six months later she is well without any symptoms. Her creatinine is $82 \mu \mathrm{mol} / \mathrm{L}$, hemoglobin is $127 \mathrm{~g} / \mathrm{L}$, and liver enzymes are completely normal. Her follow up chest x-ray was also completely normal (Figure 2).

\section{DISCUSSION}

Infection with parvovirus B19 has protean manifestations. In children, the symptoms are similar to many other viral illnesses with fever, nausea, diarrhea, malaise and cough. The bright red facial rash, the so called 'slapped cheek' phenomenon, is a characteristic but not pathognomonic finding.

Adults may develop more severe sequelae from parvovirus B19 infection. Polyarthropathy involving the hands, wrists, knees, ankles and feet is the most common finding and may be painful enough to impair dexterity and mobility (9). Anemia, caused by the lysis of red blood cell precursors, is usually mild because the duration of the illness is typically much shorter than the average erythrocyte lifespan (6). In patients with chronic hemolytic anemias, the anemia may become much more severe, and they may develop life threatening marrow aplasia.

We describe three new, previously unreported clinical manifestations associated with acute parvovirus B19 infection in adults. The acute renal failure in our patient was suspected to be secondary to a postinfectious tubulointerstitial process. This was suggested by a bland urinary sediment without any hematuria or proteinuria and the absence of risk factors for ischemic or toxic acute tubular necrosis. Antistreptolysin $\mathrm{O}$ titre and anti-DNase B were not checked because clinical presentation without nephritic urine sediment is not in keeping with poststreptococcal glomerulonephritis. No kidney biopsy was performed because serum creatinine was already on the decline at the time of nephrological assessment, and results, therefore, would not alter management. The acute renal failure was self-limiting, and the patient did not require any dialysis.

Transient elevations were noted in her hepatocellular enzymes without any jaundice or manifestations of hepatic failure. These abnormalities were present several days before the onset of congestive heart failure and were suggestive of mild acute viral hepatitis or parainfectious hepatic involvement rather than passive hepatic congestion. As the heart failure became clinically apparent the liver enzyme levels were already improving and, therefore, the courses of the two abnormalities diverged. Once again, this finding is not in keeping with passive hepatic congestion.

Cardiac involvement with parvovirus B19 has been implicated in the pathogenesis of nonimmune hydrops fetalis; however, this has not been reported in adults. The puzzling feature of this patient's cardiac disease was the demonstration of very mild systolic dysfunction and no diastolic dysfunction, based on echocardiogram and nuclear wall motion study, in the face of quite significant clinical and radiological manifestations of congestive heart failure. The most plausible explanation is that the formal cardiac assessment was carried out a few days after the onset of her symptoms of congestive heart failure, at which time myocardial function had already started to improve and, thus, the nadir of systolic function was missed. Other possible explanations may include the concomitant presence of a virus-induced pulmonary capillary leak, interstitial pneumonia or a subclinical component of diastolic dysfunction that was not detected by echocardiography.

\section{CONCLUSION}

Systemic disease with renal, cardiac and hepatic involvement can occur in association with parvovirus B19 infection in adults, and infection with this agent should be suspected in patients with this constellation of organ involvement and who have a recent history of exposure.

\section{REFERENCES}

1. Cossart YE, Field AM, Cant B, et al. Parvovirus-like particles in human sera. Lancet 1975;i:72-3.

2. Serjeant GR, Topley JM, Mason K, et al. Outbreak of aplastic crisis in sickle cell anemia associated with parvovirus-like agent. Lancet 1981;ii:595-7.

3. Naides SJ, Field EH. Transient rheumatoid factor positivity in acute human parvovirus B19 infection. Arch Intern Med 1988;148:2587-9.

4. Anderson MJ, Jones SE, Fisher-Jock SP, et al. Human parvovirus, the cause of erythema infectiosum (fifth disease). Lancet 1983;i:1378.

5. Anderson LJ. The role of parvovirus B19 in human disease. Pediatr Infect Dis J 1987;6:711-81.

6. Hoeprich PD, Jordan MC, Ronald AR. Infectious Diseases, 5th edn. Philadelphia: JB Lippincott Company, 1994:912-4.

7. Centers for Disease Control. Risks associated with human parvovirus B19 infection. MMWR 1989;38:81-8.

8. Torok TJ. Parvovirus B19 and human disease. Adv Intern Med 1992;37:431-55

9. Reid DM, Reid TM, Brown T, et al. Human parvovirus associated arthritis. A clinical and laboratory description. Lancet 1985;i:422-5. 


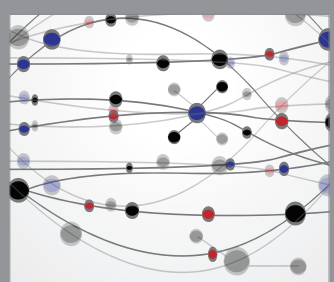

The Scientific World Journal
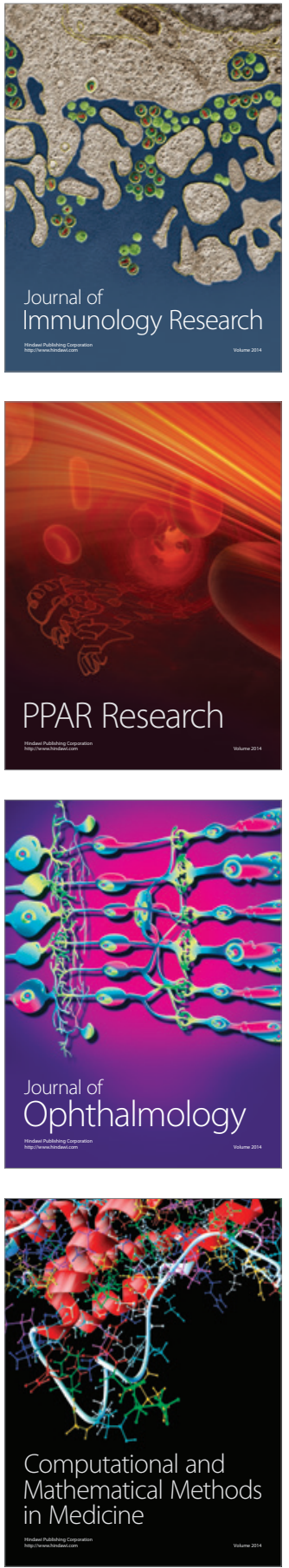

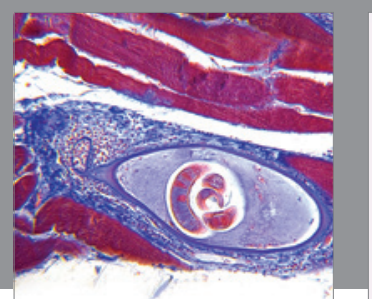

Gastroenterology Research and Practice

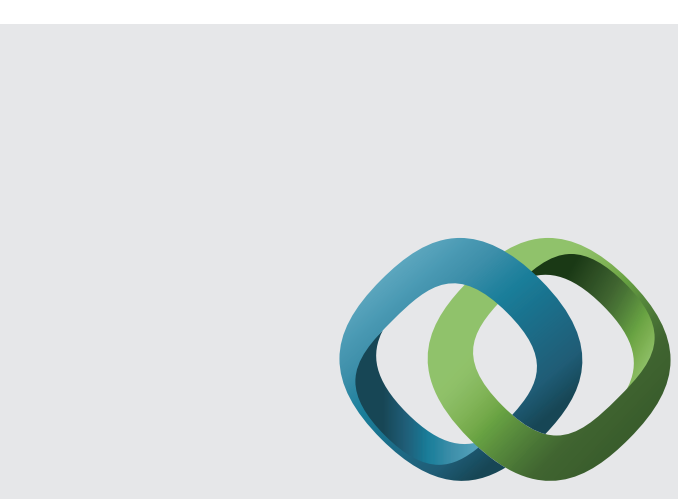

\section{Hindawi}

Submit your manuscripts at

http://www.hindawi.com
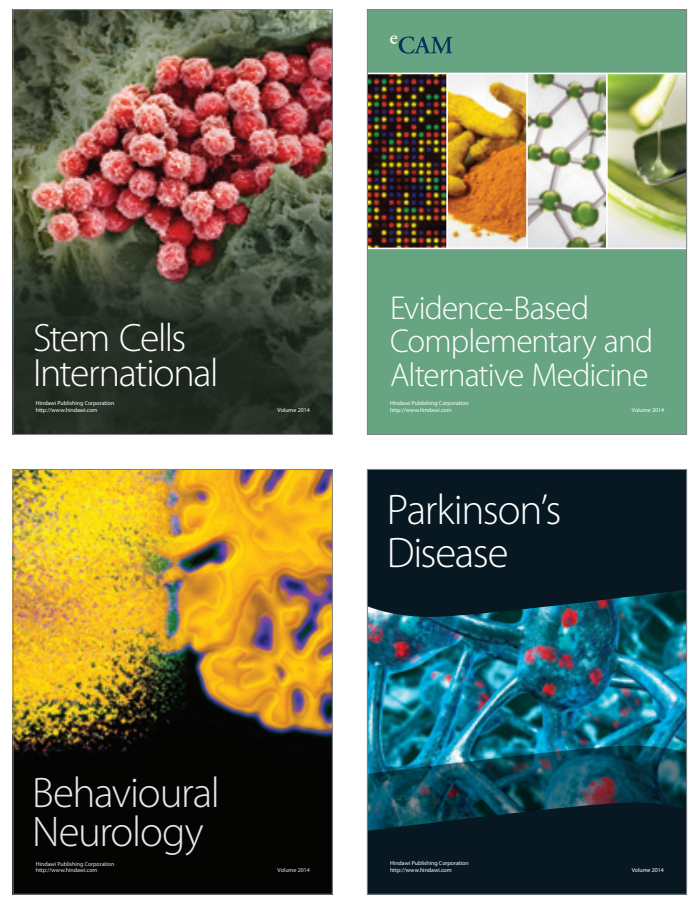
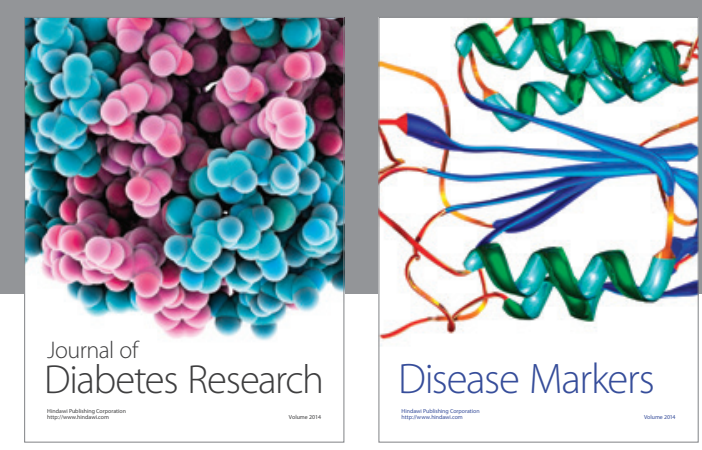

Disease Markers
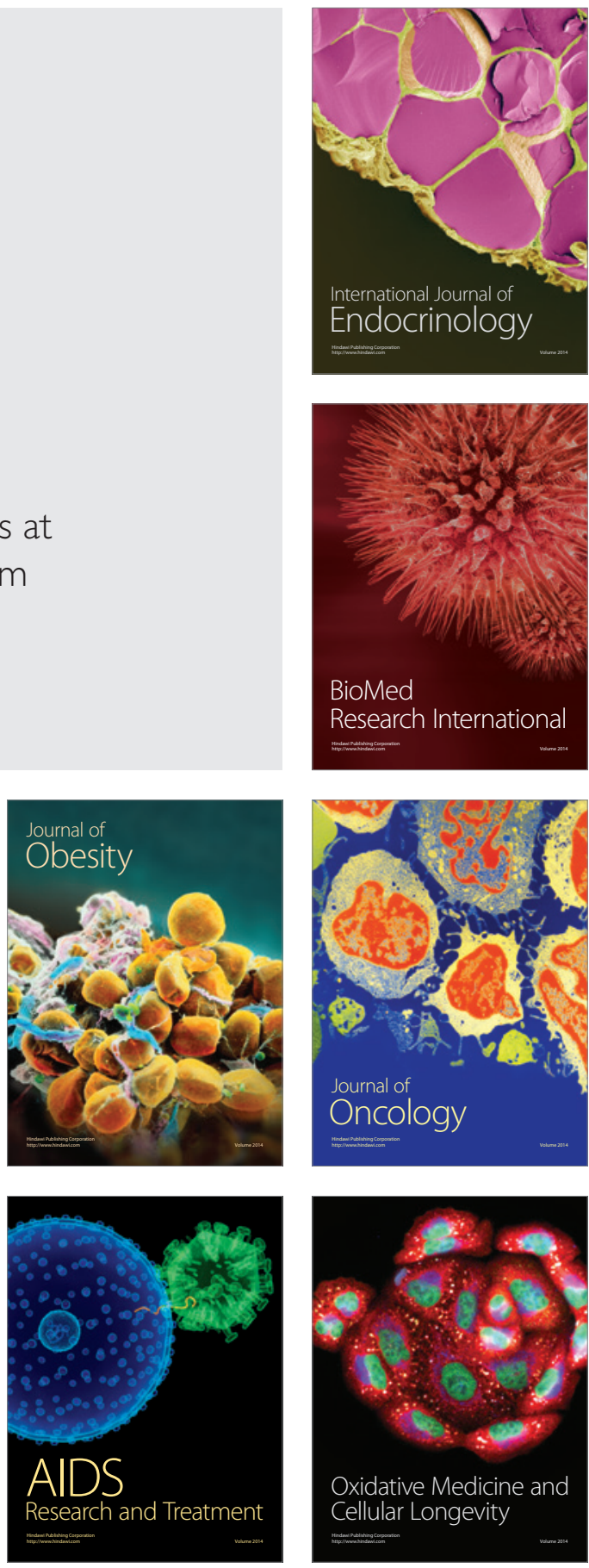